International Research Journal of Management, IT \& Social Sciences
Available online at https://sloap.org/journals/index.php/irjmis/
Vol. 9 No. 1, January 2022, pages: 159-167
ISSN: 2395-7492
https://doi.org/10.21744/irjmis.v9n1.2035

\title{
The Effect of Regulation, Accountability Systems, Accounting Principles, Priority Programs on Performance Accountability and Performance Reporting Moderates of Good Financial Governance of Village
}

Article history:

Submitted: 27 November 2021

Revised: 18 December 2021

Accepted: 09 January 2022

\section{Keywords:}

accounting principles; performance accountability systems;

performance accountability; performance reports;

regulations;

\begin{abstract}
Research to prove, analyze and interpret the Effect of Regulation, Accountability System, Accounting Principles, Priority Programs on Performance Accountability, and Performance Reports in Village Fund Management with Moderate Variables Good Financial Governance (GFG) Village. This study uses a quantitative approach by collecting data through a survey of village heads who receive village funds. This study uses an explanatory approach by testing some hypotheses. The study population was in all villages receiving village funds in Tulungagung Regency in 2021. The number of samples was determined using the Slovin formula with a tolerance of 5\% as many as 156 respondents. Sampling was done using Random Sampling, while the data analysis technique used Partial Least Square. Regulation, work accountability, accounting principles partially have a significant effect on performance Reports. Priority Programs have a significant effect on Performance AccountabilityandGFG can strengthen the relationship between the Village Fund Accounting Principles and the performance report.
\end{abstract}

International research journal of management, IT and social sciences (C) 2022. This is an open access article under the CC BY-NC-ND license (https://creativecommons.org/licenses/by-nc-nd/4.0/).

\section{Corresponding author:}

Wenni Wahyuandari,

Doctoral Candidate of 17 Agustus 1945 University, Surabaya, Indonesia.

Email address: wwahyuandari@gmail.com

\footnotetext{
17 Agustus 1945 University, Surabaya, Indonesia

17 Agustus 1945 University, Surabaya, Indonesia

17 Agustus 1945 University, Surabaya, Indonesia
} 


\section{Introduction}

Government Regulation of the Republic of Indonesia Number: 60 of 2014 Village Fund which is a fund sourced from the State Revenue and Expenditure Budget designated for Villages which is transferred through the Regency or City Regional Revenue and Expenditure Budget and is used to finance government administration, implementation of development, community development, and community empowerment (Triyono et al., 2019; Alfasadun et al., 2018; Amalya \& Akram, 2017; Atmadja et al., 2018). The central government has budgeted a fairly large Village Fund since 2015. Based on data from the Ministry of Finance in 2020, the sharpest increase occurred in 2016, namely $125 \%$ to Rp. 46.9 trillion from the previous year, Rp. 20.8 trillion in 2015. The Village Fund budget plan per 2020 increased $2.9 \%$ from the previous year to IDR 72 trillion, while in 2018 it was IDR 60 trillion, in 2019 the budget was IDR 70 trillion

One of the districts in Indonesia that receive village funds from the State Revenue and Expenditure Budget is Tulungagung district, East Java province (Baswir, 1989; Budiana et al., 2019). The Village Fund has been distributed to 257 villages in 18 sub-districts in the Tulungagung district, as shown in table 1.

Table 1

Tulungagung regency village fund realization data from APBN transfer 2015-2020 period

\begin{tabular}{rr}
\hline Year & Village Fund (Rp) \\
\hline 2015 & $71,037,288,000$ \\
2016 & $159,404,476,000$ \\
2017 & $203,074,565,000$ \\
2018 & $205,952,328,000$ \\
2019 & $233,413,883,000$ \\
2020 & 234.886 .567 .000 \\
Total & $1,107,769,107,000$ \\
\hline
\end{tabular}

Source: Siskeudes Tulungagung, 2020

Table 1 shows that the realization of the Tulungagung district village funds received from The State Revenue and Expenditure Budget from 2015-2020 amounts to 1,107 billion which will be used for village development programs. Villages that have received village funds are required to account for the management of the funds to the government (Dagiliené \& Mykolaitiené, 2015; Shields, 1980; Nazari et al., 2017). Based on the Regulation of the Minister of State Apparatus Empowerment No: 35 of 2014 the preparation of the Performance Accountability Report of Government Agencies is a form of accountability from the implementation of the tasks and functions entrusted to each government agency for the use of the budget (Bustaman et al., 2018; Diansari, 2015; Arifiyanto \& Kurrohman, 2014). Village financial management must be based on the principles of transparency, accountability and managed in an open, accountable, and following regulations (Purnomo et al., 2020; Battmann \& Klumb, 1993).

Public regulations are provisions that must be implemented and obeyed in the process of managing public organizations, both in central government organizations, regional governments, political parties, foundations, NGOs, religious organizations/places of worship, as well as other social organizations (Aziiz \& Prastiti, 2019; Salindeho et al., 2017) which is easy to understand will have an impact on the Performance Reports of Government Agencies (Lisa Baudot et al., 2021). Financial Accountability of Government Agencies is the principle of government accountability which means that the budgeting process starting from planning, preparation, and implementation must be reported and accounted for to the public (Dillard \& Vinnari, 2019; Bracci, 2009).

An understanding of village fund management regulations shows that the accountability of the performance of village government agencies is good (Baudot \& Cooper, 2021; Salindeho et al., 2017; Agoraki et al., 2011). Regulation of the Minister of Villages for Development of Disadvantaged Regions and Transmigration of the Republic of Indonesia Number 11 of 2019 concerning Priority for the Use of Village Funds in 2020 that the Priority Program of Village Funds is the use of Village Funds as public funds compiled based on the principles of priority needs, justice, village authority, focus, participatory, self-management, and based on village resources (Frayudha, 2016; Gimon et al., 2018; Hendrawati et al., 2018; Kurrohman, 2015; Hirnissa \& Zariyawati, 2017; Makalalag, et al., 2017). A better understanding of priority programs in the financial management of village funds will show a good direction in the implementation of government agency performance accountability (Baudot \& Cooper, 2021; Muljo et al., 2014; Dewi Gayatri, 2019). 
Good Financial Governance must is committed to the implementation of regional/village financial management. Accounting principles strengthened by GFG will make a good performance report (Carpenter \& Feroz, 1992; Zeff, 2007). Safitri \& Fathah (2018), GFG in the implementation of regional or village financial management is used to achieve the ideals and goals of the state, namely the welfare of the community, avoiding various irregularities in regional financial management. Good governance will be built on Good financial governance (Umar et al., 2018; Wau \& Ratmono, 2015; Widarnawati et al., 2018; Carpenter \& Feroz, 2001).

\section{Literature review}

Government Agencies Performance Reports are a form of accountability for the implementation of tasks and functions entrusted to each government agency in the use of the budget (Maritafitri \& Achadiyah, 2018; Asmony, 2018; Mutmainah \& Pramuka, 2017; Nafidah \& Anisa, 2017; Nurhakim \& Yudianto, 2018). The most important thing needed in preparing the report is performance measurement and evaluation as well as adequate disclosure of the results of the analysis of performance measurement (Minister of Administrative Reform Regulation No: 53, 2014). The implementation of the principles of good financial governance in the laws and regulations relating to the management of state finances will be able to create clean governance (Indrawati, 2012; Hidah \& Sedana, 2021; Jaeng et al., 2019).

Village fund regulation following the Village Law No 6 year 2014is a rule used in the management of Measurement indicators related to responses to government regulations on village fund management, support for programs, and implementation of Village Fund management rules (Riyanto, 2016). Government Agency Performance Accountability System is a systematic series of various activities, tools, and procedures designed to determine, measure, collect data, classify, summarize, and report performance to government agencies, in the context of accountability and performance improvement of government agencies (Mardiasmo, 2002).

System Performance Accountability of Government Agencies is an order, instrument, and method of accountability which essentially includes certain stages, then the performance achievements are reported to interested parties (Mardiasmo, 2002). Accountability for the Performance of Village Government Agencies contained in the Minister of Home Affairs Regulation Number 20 of 2018 is the principle of village government accountability which means that the budgeting process starting from planning, preparation, and implementation must be reported and accounted for to the community (Putra \& Rasmini, 2019; Putra et al., 2017; Muchlis \& Rabb, 2016; Rasmi et al., 2018; Setiawan et al., 2017; Wida et al., 2017; Subandi \& Fadhil, 2018).

Accounting principles are used for uniformity in terms, ways, methods, certain procedures to produce financial report format relevant and easily understood by the public (Mardiasmo, 2002). Based on the Regulation of the Minister of Villages, Development of Disadvantaged Regions and Transmigration of the Republic of Indonesia No. 11 of 2019 concerning Priority for the Use of Village Funds that the choice of activities takes precedence and takes precedence over other activity options that will be financed with the Village Fund (Yunita \& Christianingrum, 2019; Yunita \& Christianingrum, 2018; Ismail et al., 2016).

\section{Materials and Methods}

This research uses a quantitative approach through a survey. The population of this research is all recipients of village funds in the Tulungagung Regency in 2021. The sampling technique uses the solving formula with a margin of relative error of 5\%. The questionnaire was distributed using a random sampling system to obtain a sample size of 156 villages. The data analysis technique used SEM-PLS with stages, namely the evaluation of the measurement model (outer model) and evaluation of the structural model (inner model), using 2 hypothesis tests, namely the direct influence test and moderation. The test criteria state that if the path coefficient has a $\mathrm{p}$-value of significance level $(\mathrm{alpha}=5 \%)$, then it is stated that there is a significant effect between the independent variables on the dependent variable. then $\mathrm{HO}$ is rejected if t-statistic $>1.96$.

\section{Results and Discussions}

Construct Reliability and Validity results in the image. 1 shows that all variables have composite reliability values > 0.7, AVE > 0.5, and Cronbach's alpha > 0.6, the consistency of indicators for each variable indicates that the four variables used in this study are reliable. Path Chart Test Output is shown in figure 2.

Wahyuandari, W., Ratnawati, T., \& Riyadi, S. (2022). The effect of regulation, accountability systems, accounting principles, priority programs on performance accountability and performance reporting moderates of good financial governance of village. International Research Journal of Management, IT and Social Sciences, 9(1), 159-167. https://doi.org/10.21744/irjmis.v9n1.2035 


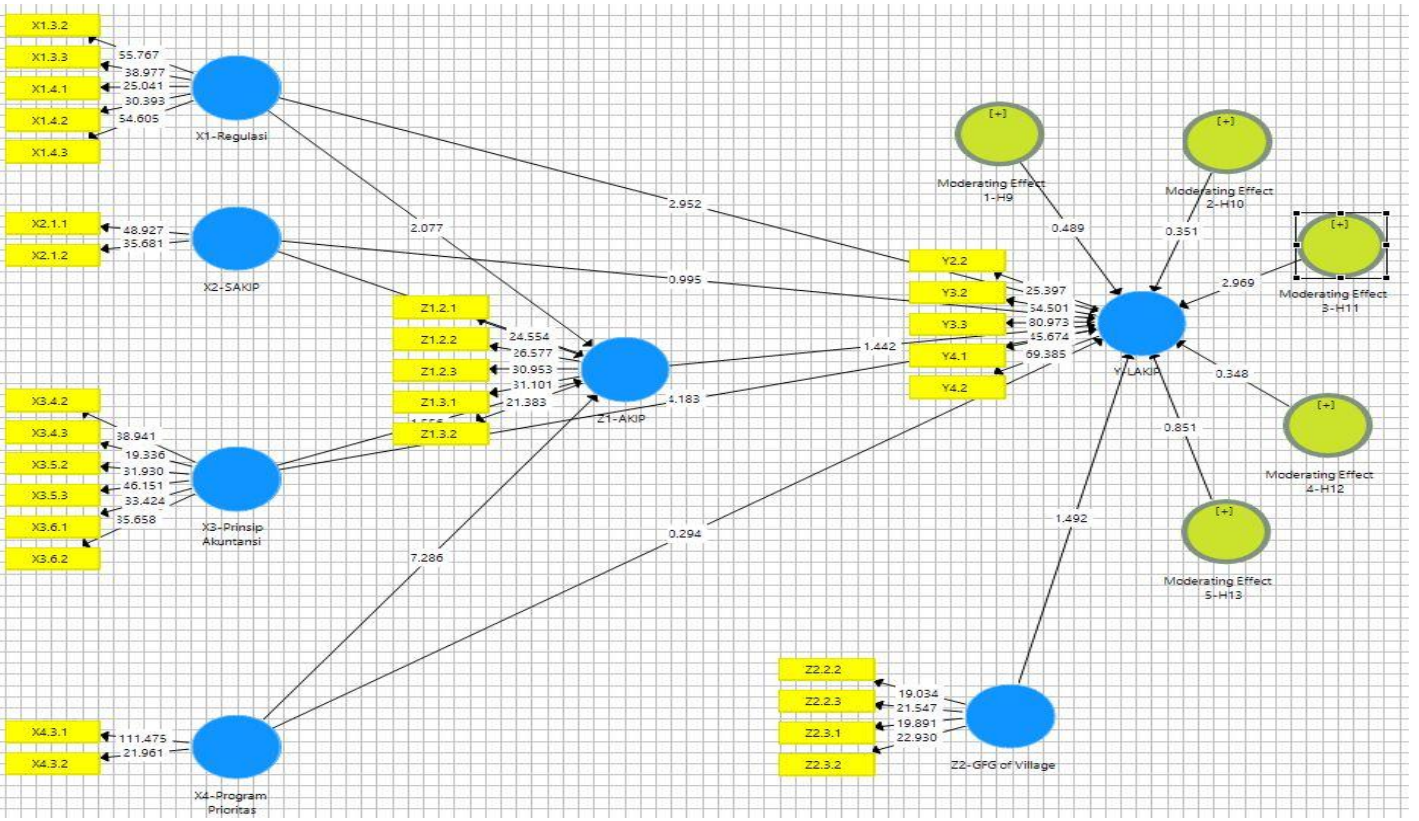

Figure 1. Path diagram testing output

Table 2

Hypothesis test results

\begin{tabular}{|c|c|c|c|c|}
\hline Hypothesis & $t$-count & t-table & $\mathrm{P}$ value & Test results \\
\hline $\begin{array}{l}\text { H1: Regulation (X1) has a significant effect on the } \\
\text { Performance Report (Y) }\end{array}$ & 2,952 & 1,967 & 0.003 & Received \\
\hline $\begin{array}{l}\text { H2: Regulation (X1) has a significant effect on } \\
\text { Performance Accountability (Z1) }\end{array}$ & 2,077 & 1,967 & 0.038 & Received \\
\hline $\begin{array}{l}\text { H3: Performance Accountability System (X2) has a } \\
\text { significant effect on Accountability Reports (Y) }\end{array}$ & 0.995 & 1,967 & 0.320 & Rejected \\
\hline $\begin{array}{l}\text { H4: Performance Accountability System (X2) has a } \\
\text { significant effect on Performance Accountability } \\
\text { (Z1) }\end{array}$ & 0.263 & 1,967 & 0.793 & Rejected \\
\hline $\begin{array}{l}\text { H5: Accounting Principles (X3) have a significant effect } \\
\text { on Accountability Reports (Y) }\end{array}$ & 4.183 & 1,967 & 0.000 & Received \\
\hline $\begin{array}{l}\text { H6: Accounting Principles (X3) have a significant effect } \\
\text { on Performance Accountability (Z1) }\end{array}$ & 1.556 & 1,967 & 0.120 & Rejected \\
\hline $\begin{array}{l}\text { H7: Priority Program (X4) has a significant effect on the } \\
\text { Accountability Report (Y) }\end{array}$ & 0.294 & 1,967 & 0.769 & Rejected \\
\hline $\begin{array}{l}\text { H8: Priority Program (X4) has a significant effect on } \\
\text { Performance Accountability (Z1) }\end{array}$ & 7.286 & 1,967 & 0.000 & Received \\
\hline $\begin{array}{l}\text { H9: Performance Accountability (Z1) has a significant } \\
\text { effect on the Accountability Report (Y). }\end{array}$ & 1,442 & 1,967 & 0.150 & Rejected \\
\hline $\begin{array}{l}\text { H10: GFG of Village (Z2) has a significant effect on the } \\
\text { Accountability Report (Y). }\end{array}$ & 1,492 & 1,967 & 0.049 & Rejected \\
\hline $\begin{array}{l}\text { H11: GFG of Village moderating the relationship between } \\
\text { Village Fund Regulations and Village Government } \\
\text { Agency Performance Reports (Y). }\end{array}$ & 0.489 & 1,967 & 0.625 & Rejected \\
\hline $\begin{array}{l}\text { H12: GFG of Village moderating the relationship between } \\
\text { the Performance Accountability System of Village } \\
\text { Government Agencies and the Performance Reports } \\
\text { of Government Agencies (Y) }\end{array}$ & 0.351 & 1,967 & 0.726 & Rejected \\
\hline
\end{tabular}




\begin{tabular}{|c|c|c|c|c|}
\hline $\begin{array}{l}\text { H13: GFG of Village moderating the relationship between } \\
\text { the Village Fund Accounting Principles and the } \\
\text { Performance Reports of Government Agencies (Y) }\end{array}$ & 2,969 & 1,967 & 0.003 & Received \\
\hline $\begin{array}{l}\text { H14: GFG of Village moderating the relationship between } \\
\text { the Village Fund Priority Program and the } \\
\text { Performance Reports of Government Agencies(Y) }\end{array}$ & 0.348 & 1,967 & 0.728 & Rejected \\
\hline $\begin{array}{l}\text { H15: GFG of Village moderating the relationship between } \\
\text { the Performance Accountability of Government } \\
\text { Agencies and the Performance Reports of } \\
\text { Government Agencies(Y) }\end{array}$ & 0.851 & 1,967 & 0.395 & Rejected \\
\hline
\end{tabular}

The results of the evaluation of hypothesis testing with SEM-PLS in table 3 show that:

a) Regulation has a significant positive effect on the Performance Reports of Government Agencies. This shows that the better the understanding and implementation of regulations in the financial management of the Village Fund, the better the implementation of the accountability report on the performance of village government agencies (Riyanto, 2016). This research is in line with (Baudot \& Cooper, 2021; Dura, 2016; Rabb \& Muchlis, 2016).

b) Regulation has a significant positive effect on the Performance Accountability of Village Government Agencies in managing village funds. This shows that the better the understanding and implementation of regulations in the financial management of Village Funds, the Accountability of Performance of Village Government Agencies in managing village funds are getting better and better (Riyanto, 2016). This research is in line with (Baudot \& Cooper, 2021; Dura, 2016; Rabb \& Muchlis, 2016).

c) The Performance Accountability System of Government Agencies has no significant effect on the Performance Accountability Report of village government agencies in managing village funds. This shows that the implementation of the Government Performance Accountability System has not been able to support the implementation of the Performance Accountability Report of Government Agencies properly. This research is contrary to (Andriani et al., 2015; Christy et al., 2017).

d) The Performance Accountability System of Government Agencies has no significant effect on the Performance Accountability of Village Government Agencies in managing village funds. This shows that the implementation of the Government Performance Accountability System has not been able to support the implementation of the Performance Accountability of Government Agencies properly. Research contradicts (Muljo et al., 2014).

e) Accounting Principles have a significant effect on the Accountability Report on the Performance of Village Government Agencies in managing village funds. This indicates that the Government Agency Performance Accountability Report has been prepared with generally accepted accounting principles following government accounting standards. This research is in line with (Farlina \& Hartono, 2019).

f) Accounting Principles have no significant effect on the Performance Accountability of Village Government Agencies in managing village funds. This shows that the accounting principles used in reporting village funds have not been understood by the village head/village treasurer in the village financial system. This study contradicts (Safitri \& Fathah, 2018; Sugiarti, 2017; Susilowati et al., 2018; Susliyanti, 2017).

g) Priority Program significant effect on the Performance Accountability Report of village government agencies in managing village funds. This shows that the implementation of priority programs has not been well understood and has not been implemented properly in the Performance Accountability Report of Government Agencies. This research is contrary to (Andriani et al., 2015)

h) Priority Program has a significant effect on the Performance Accountability of Village Government Agencies in managing village funds. This shows that the implementation of priority programs is following the accountability principle of Performance Accountability of Government Agencies. This research is in line with (Indrawati, 2012; Syaifullah, 2017; Tambuwun et al., 2018; Tikollah \& Ngampo, 2018).

i) Government Agency Performance Accountability has no significant effect on Agency Performance Accountability Report Village government in managing village funds. This shows that the principle of accountability in the Performance of Government Agencies has not been implemented optimally in reporting performance. This study contradicts (Safitri \& Fathah, 2018).

j) GFG of Village has no significant effect on the Report Performance Accountability of Village Government Agencies in managing village funds. This study contradicts (Safitri \& Fathah, 2018).

Wahyuandari, W., Ratnawati, T., \& Riyadi, S. (2022). The effect of regulation, accountability systems, accounting principles, priority programs on performance accountability and performance reporting moderates of good financial governance of village. International Research Journal of Management, IT and Social Sciences, 9(1), 159-167. https://doi.org/10.21744/irjmis.v9n1.2035 
k) GFG of Village can't strengthen the relationship between Village Fund Regulations and Village Government Agency Performance Reports. This study contradicts (Safitri \& Fathah, 2018).

1) GFG of Village can't be moderating the relationship between skip and Government Agencies Performance Report. This suggests that (This study contradicts (Safitri \& Fathah, 2018).

m) GFG of Village can be moderating the relationship between the Village Fund accounting principles and the Performance Reports of Government Agencies. This study is in line with (Safitri \& Fathah, 2018).

n) GFG of Village can't be moderating the relationship between priority programs and Government Agencies Performance Reports This study contradicts (Indrawati, 2012).

o) GFG of Village does not moderate the relationship between the Performance Accountability of Government Agencies with the Performance Reports of Government Agencies This study contradicts (Indrawati, 2012).

\section{Conclusion}

This research aims to prove the relationship between the variables that influenceReport on the Performance of Village Government Agencies in managing village funds GFG of Village as a moderating variable. The results showed that the regulation proved to have a significant effect on the Performance Accountability Report of village government agencies and the Performance Accountability of Government Agencies. Priority Programs are proven to have a significant effect on the Performance Accountability of Government Agencies with the support of a positive direction. This shows that the understanding and implementation of priority programs are getting better. Accountability System, Accounting Principles, Priority Programs, Performance Accountability of Government Agencies proved to have no significant effect on the Performance Reports of Government Agencies.

\section{Conflict of interest statement}

The authors declared that they have no competing interests.

\section{Statement of authorship}

The authors have a responsibility for the conception and design of the study. The authors have approved the final article.

Acknowledgments

We are grateful to two anonymous reviewers for their valuable comments on the earlier version of this paper. 


\section{References}

Agoraki, M. E. K., Delis, M. D., \& Pasiouras, F. (2011). Regulations, competition and bank risk-taking in transition countries. Journal of Financial Stability, 7(1), 38-48. https://doi.org/10.1016/j.jfs.2009.08.002

Alfasadun, A., Hardiningsih, P., \& Srimindarti, C. (2018). Transparansi dan Akuntabilitas Pengelolaan Dana Desa.

Amalya, T., \& Akram, E. P. (2017). Determinants of Village Financial Management and Its Implication toward Accountability: Study on Village Governance in West Lombok Regency. International Journal of Research in Advent Technology, 5(12), 15-23.

Andriani, W., Rosita, I., \& Ihsan, H. (2015). Penerapan Sistem Akuntabilitas Kinerja Instansi Pemerintah (Sakip) Dalam Mewujudkan Good Governance Pada Politeknik Negeri Padang. Akuntansi dan Manajemen, 10(2), 51-60.

Arifiyanto, D. F., \& Kurrohman, T. (2014). Akuntabilitas pengelolaan alokasi dana desa di Kabupaten Jember. Jurnal Riset Akuntansi dan Keuangan, 2(3).

Asmony, T. (2018). Menyibak Tabir Pengelolaan Dana Desa Dari Perspektif Habermas. Akurasi: Jurnal Studi Akuntansi dan Keuangan, 1(1), 63-75.

Atmadja, A. T., Saputra, K. A. K., \& Koswara, M. K. (2018). The Influence Of Village Conflict, Village Apparatus Ability, Village Facilitator Competency And Commitment Of Local Government On The Success Of Budget Management. Academy of Accounting and Financial Studies Journal, 22(1), 1-11.

Aziiz, M. N., \& Prastiti, S. D. (2019). Faktor-Faktor Yang Mempengaruhi Akuntabilitas Dana Desa. Jurnal Akuntansi Aktual, 334.

Baswir, R. (1989). Akuntansi Pemerintahan Indonesia. BPFE Yogyakarta.

Battmann, W., \& Klumb, P. (1993). Behavioural economics and compliance with safety regulations. Safety Science, 16(1), 35-46. https://doi.org/10.1016/0925-7535(93)90005-X

Baudot, L., \& Cooper, D. J. (2021). Regulatory mandates and responses to uncomfortable knowledge: The case of country-by-country reporting in the extractive sector. Accounting, Organizations and Society, 101308. https://doi.org/10.1016/j.aos.2021.101308

Baudot, L., Huang, Z., \& Wallace, D. (2021). Stakeholder perceptions of risk in mandatory corporate responsibility disclosure. Journal of Business Ethics, 172(1), 151-174.

Bracci, E. (2009). Autonomy, responsibility and accountability in the Italian school system. Critical perspectives on accounting, 20(3), 293-312. https://doi.org/10.1016/j.cpa.2008.09.001

Budiana, D. A., Said, D., \& Sodiq, N. (2019). The Effect Of Village Device Competencies And Internal Control System On Accountability Of Village Management. Scientific Research Journal, 1(7), 10-20.

Bustaman, B., Amalia, E., \& Jalaluddin, J. (2018). A Performance Analysis of Village Fund Management: A Case Study in Lut Tawar District-Indonesia. Journal of Accounting Research, Organization and Economics, 1(2), 112121.

Carpenter, V. L., \& Feroz, E. H. (1992). GAAP as a symbol of legitimacy: New York State's decision to adopt generally accepted accounting principles. Accounting, Organizations and Society, 17(7), 613-643. https://doi.org/10.1016/0361-3682(92)90016-L

Carpenter, V. L., \& Feroz, E. H. (2001). Institutional theory and accounting rule choice: an analysis of four US state governments' decisions to adopt generally accepted accounting principles. Accounting, organizations and society, 26(7-8), 565-596. https://doi.org/10.1016/S0361-3682(00)00038-6

Christy, Y., Setiana, S., \& Cintia, P. (2017). Efektivitas Penerapan Sistem Akuntabilitas Kinerja Instansi Pemerintah (SAKIP) pada Pemerintahan Daerah Kota Bandung (Studi Kasus pada Badan Kepegawaian, Pendidikan dan Pelatihan; Bagian Umum dan Perlengkapan dan Badan Kesatuan Bangsa dan Politik). Jurnal Akuntansi, 9(2).

Dagiliené, L., \& Mykolaitiené, V. (2015). Disclosure of social responsibility in annual performance reports of universities. Procedia-Social and Behavioral Sciences, 213, 586-592. https://doi.org/10.1016/j.sbspro.2015.11.454

Dewi, N. K. A. J. P. Gayatri. (2019). Faktor-faktor yang berpengaruh pada akuntabilitas pengelolaan dana desa. $E$ Jurnal Akuntansi Universitas Udayana, 26(2), 1269-1298.

Diansari, R. E. (2015). Analisa Implementasi Alokasi Dana Desa (ADD) Kasus Seluruh Desa Di Kecamatan Kledung Kabupaten Temanggung Tahun 2013.

Dillard, J., \& Vinnari, E. (2019). Critical dialogical accountability: From accounting-based accountability to accountability-based accounting. Critical Perspectives on Accounting, 62, 16-38. https://doi.org/10.1016/j.cpa.2018.10.003

Dura, J. (2016). Pengaruh akuntabilitas pengelolaan keuangan alokasi dana desa, kebijakan desa, dan kelembagaan desa terhadap kesejahteraan masyarakat. Jurnal Ilmiah Bisnis dan Ekonomi Asia, 10(2), 26-32.

Farlina, W., \& Hartono, Y. (2019). Analysis Of Factors That Influence On Reporting Of Dana Desa Programs. Jurnal

Wahyuandari, W., Ratnawati, T., \& Riyadi, S. (2022). The effect of regulation, accountability systems, accounting principles, priority programs on performance accountability and performance reporting moderates of good financial governance of village. International Research Journal of Management, IT and Social Sciences, 9(1), 159-167. https://doi.org/10.21744/irjmis.v9n1.2035 
Apresiasi Ekonomi, 7(2), 192-201.

Frayudha, A. (2016). Akuntabilitas Pengelolaan Keuangan Desa Tahun Anggaran 2015 di Kecamatan Sintang Kabupaten Sintang. Jurnal Ekonomi Daerah (JEDA), 5(3).

Gimon, H. P., Tinangon, J. J., \& Affandi, D. (2018). Analisis sistem akuntansi pelaksanaan APBDes pada pemerintah desa Kopandakan I Kecamatan Kotamobagu Selatan Kota Kotamobagu. Going Concern: Jurnal Riset Akuntansi, 13(02).

Hendrawati, E., Bararoh, T., \& Pramudianti, M. (2018). Fund Management and Allocation of Funds for Rural Village: Challenges of Budget Preparation, Implementation and Reporting Accounting.

Hidah, M., \& Sedana, I. B. P. (2021). The role of corporate social responsibility and earning management in mediation of the effect of corporate governance on corporate performance. International Research Journal of Management, IT and Social Sciences, 8(5), 322-332. https://doi.org/10.21744/irjmis.v8n5.1903

Hirnissa, M. T., \& Zariyawati, M. A. (2017). How working capital management affects the profitability of small and medium size enterprises (SMEs) In Malaysia. International Journal of Economics, Business and Management Research, 1(4), 433-445.

Indrawati, N. (2012). Analisis faktor-faktor yang mempengaruhi underpricing pada penawaran umum perdana. Jurnal Akuntansi dan Bisnis, 5(1).

Ismail, M., Widagdo, A. K., \& Widodo, A. (2016). Sistem akuntansi pengelolaan dana desa. Jurnal Ekonomi dan Bisnis, 19(2), 323-340.

Jaeng, W. M. Y., Suardikha, I. M. S., \& Budiasih, I. G. A. N. (2019). Effect of use of regional financial management information systems on individual performance in BPKAD Sikka Regency. International Research Journal of Management, IT and Social Sciences, 6(6), 188-193. https://doi.org/10.21744/irjmis.v6n6.790

Kurrohman, T. (2015). Accountability of planning on village fund allocation in osing community in Banyuwangi.

Makalalag, A. J., Nangoi, G. B., \& Karamoy, H. (2017). Akuntabilitas pengelolaan dana desa di kecamatan Kotamobagu Selatan kota Kotamobagu. JURNAL RISET AKUNTANSI DAN AUDITING" GOODWILL", 8(1).

Mardiasmo. (2002). Akuntansi Sektor Publik (Edisi Kedua). Yogyakarta: Andi.

Maritafitri, D., \& Achadiyah, B. N. (2018). Phenomenological Study on the Village Fund Accountability. KnE Social Sciences, 51-70.

Muchlis, M., \& Rabb, A. D. A. (2016). Implementasi Kebijakan Dana Desa Berdasarkan Peraturan Menteri Keuangan Nomor 93 Tahun 2015 Pada Kecamatan Ganra Kabupaten Soppeng. Jurnal Ilmiah Akuntansi Peradaban, 2(2).

Muljo, H. H., Kurniawati, H., \& Pahala, P. (2014). Pengaruh Akuntabilitas dan Transparansi terhadap Pengelolaan Anggaran. Binus Business Review, 5(2), 537-550.

Mutmainah, I., \& Pramuka, B. A. (2017). Penerapan akuntabilitas pengelolaan dana desa dan Sistem Pengendalian Intern Pemerintah (SPIP) di Kecamatan Kedungwuni Kabupaten Pekalongan. Jurnal Ekonomi, Bisnis, dan Akuntansi, 19(4).

Nafidah, L. N., \& Anisa, N. (2017). Akuntabilitas pengelolaan keuangan desa di kabupaten Jombang. Jurnal Ilmu Akuntansi, 10(2), 273-288.

Nazari, J. A., Hrazdil, K., \& Mahmoudian, F. (2017). Assessing social and environmental performance through narrative complexity in CSR reports. Journal of Contemporary Accounting \& Economics, 13(2), 166-178. https://doi.org/10.1016/j.jcae.2017.05.002

Nurhakim, I., \& Yudianto, I. (2018). Implementation of Village Fund Management. Journal of Accounting Auditing and Business, 1(2), 39-55.

Purnomo, S., Rahayu, E. S., Riani, A. L., Suminah, S., \& Udin, U. D. I. N. (2020). Empowerment model for sustainable tourism village in an emerging country. The Journal of Asian Finance, Economics, and Business, 7(2), 261-270.

Putra, I. M. Y. D., \& Rasmini, N. K. (2019). Pengaruh Akuntabilitas, Transparansi, dan Partisipasi Masyarakat Pada Efektivitas Pengelolaan Dana Desa. E-Jurnal Akuntansi, 28(1), 132-158.

Putra, I. P. A. S., Sinarwati, N. K., \& Wahyuni, M. A. (2017). Akuntabilitas dan Transparansi Pengelolaan Alokasi Dana Desa (ADD) di Desa Bubunan, Kecamatan Seririt, Kabupaten Buleleng. JIMAT (Jurnal Ilmiah Mahasiswa Akuntansi) Undiksha, 8(2).

Rasmi, D., Salle, A., \& Pangayow, B. J. (2018). Analisis pengelolaan dan pertanggungjawaban keuangan kampung. Jurnal Akuntansi dan Keuangan Daerah, 13(1), 83-95.

Riyanto, A. (2016). Keuangan Desa. 1-50.

Safitri, T. A., \& Fathah, R. N. (2018). Pengelolaan Alokasi Dana Desa Dalam Mewujudkan Good Governance. Jurnal Litbang Sukowati: Media Penelitian Dan Pengembangan, 2(1), 89-105.

Salindeho, M. M., Kalangi, L., \& Warongan, J. (2017). Analisis Pengelolaan Dan Pemanfaatan Dana Desa Di 
Kecamatan Damau Kabupaten Kepulauan Talaud. Jurnal Riset Akuntansi Dan Auditing" Goodwill", 8(2).

Setiawan, M. W., Atmadja, A. T., SE, A., \& Sulindawati, N. L. G. E. (2017). Analisis Transparansi dan Akuntabilitas Pelaporan Alokasi Dana Desa (Studi Kasus Desa Bengkel, Kec. Busungbiu, Kab. Buleleng). JIMAT (Jurnal Ilmiah Mahasiswa Akuntansi) Undiksha, 7(1).

Shields, M. D. (1980). Some effects on information load on search patterns used to analyze performance reports. Accounting, Organizations and Society, 5(4), 429-442. https://doi.org/10.1016/0361-3682(80)90041-0

Subandi, H., \& Fadhil, M. I. I. (2018). Analisis Faktor-Faktor Yang Mempengaruhi Kepatuhan Pajak Bendahara Desa Di Kota Batu. Berkala Akuntansi dan Keuangan Indonesia, 3(1), 1-16.

Sugiarti, E. (2017). Analisis Faktor Kompetensi Sumber Daya Manusia, Pemanfaatan Teknologi Informasi, Dan Partisipasi Penganggaran Terhadap Akuntabilitas Pengelolaan Dana Desa (Survei Pada Desa-Desa di Wilayah Kecamatan $K$ (Doctoral dissertation).

Susilowati, N., Herdiani, A., \& Widhiastuti, R. (2018). Village Community Participation Model in Village Funds Management to Exteriorize the Accountability. KnE Social Sciences, 1024-1038.

Susliyanti, E. D. (2017). Transparansi Dan Akuntabilitas Alokasi Dana Desa (Studi pada Desa Trimulyo, Kecamatan Jetis, Kabupaten Bantul Tahun 2015). Wahana: Jurnal Ekonomi, Manajemen dan Akuntansi, 20(1), 16-26.

Syaifullah, M. (2017). Understanding of village apparatus on implementation accounting villages. International Journal of Science and Research, 6(8), 1168-1175.

Tambuwun, F. V., Sabijono, H., \& Alexander, S. W. (2018). Analisis Transparansi Dan Akuntabilitas Otonomi Desa Dalam Pengelolaan Dan Pertanggungjawaban Alokasi Dana Desa Di Desa Kauneran Satu Kecamatan Sonder Kabupaten Minahasa. GOING CONCERN: JURNAL RISET AKUNTANSI, 13(04).

Tikollah, M. R., \& Ngampo, M. Y. A. (2018). Analisis Pengelolaan Alokasi Dana Desa (ADD) Di Kecamatan Mare Kabupaten Bone. JEKPEND: Jurnal Ekonomi dan Pendidikan, 1(1), 87-96.

Triyono, T., Achyani, F., \& Arfiansyah, M. A. (2019). The determinant accountability of village funds management (study in the villages in Wonogiri District). Riset Akuntansi Dan Keuangan Indonesia, 4(2), 118-135.

Umar, H., Usman, S., \& Purba, R. B. (2018). The influence of internal control and competence of human resources on village fund management and the implications on the quality of village financial reports. International Journal of Civil Engineering and Technology, 9(7), 1523-1531.

Wau, I., \& Ratmono, D. (2015). Analisis Faktor-Faktor yang Mempengaruhi Ketersediaan dan Keteraksesan Internet Financial Reporting oleh Pemerintah Daerah (Doctoral dissertation, Fakultas Ekonomika dan Bisnis).

Wida, S. A., Supatmoko, D., \& Kurrohman, T. (2017). Akuntabilitas Pengelolaan Alokasi Dana Desa (ADD) di DesaDesa Kecamatan Rogojampi Kabupaten Banyuwangi. E-Journal Ekonomi Bisnis Dan Akuntansi, 4(2), 148-152.

Widarnawati, B. W., Santoso, B., \& Suparman, L. (2018). Factors Affecting of Village Financial Management and Its Implication for Stakeholders Trust (Studi on Villages in Central Lombok, Indonesia). International Journal of Economics, Commerce and Management, 4(3), 2348-0386.

Yunita, A., \& Christianingrum, C. (2019). Evaluasi Akuntabilitas Dan Efektivitas Pengelolaan Dana Desa Di Kabupaten Bangka Dan Kabupaten Belitung: Suatu Kajian Komprehensif. Tirtayasa Ekonomika, 14(1), 66-77.

Yunita, A., \& Christianingrum, M. (2018). Measurement of Accountability Management of Village Funds. Integrated Journal of Business and Economics, 2(1), 99-103.

Zeff, S. A. (2007). The membership of the accounting principles board. Research in Accounting Regulation, 19, 207214. https://doi.org/10.1016/S1052-0457(06)19010-4

Wahyuandari, W., Ratnawati, T., \& Riyadi, S. (2022). The effect of regulation, accountability systems, accounting principles, priority programs on performance accountability and performance reporting moderates of good financial governance of village. International Research Journal of Management, IT and Social Sciences, 9(1), 159-167. https://doi.org/10.21744/irjmis.v9n1.2035 